\title{
Analysis of tree species, preferences by farmers in Albertine rift, Uganda
}

\author{
Charles Lwanga Tumuhe $^{(1,2)^{*}}$, Sylvia Nyamaizi ${ }^{(3)}$ \\ ${ }^{(1)}$ Department of environmental management, Makerere University, P. O. BOX 7062, Kampala \\ Uganda \\ ${ }^{(3)}$ Faculty of technologies for rural transformation, African Rural University, P O BOX 24, Kagadi, \\ Uganda \\ ${ }^{(2)}$ School of Agricultural Sciences, Makerere University, P. O. BOX 7062, Kampala Uganda
}

Received: 20 December 2018

Accepted: 21 November 2020

Published online: 31 December 2020

\begin{abstract}
There have been several efforts to plant trees in Uganda but the rate of tree planting has remained low perhaps due to coercing farmers to plant the tree species against their preference. In this study, the tree species' preferences of farmers in Albertine rift are presented. Key informant interviews, focus group interviews and semi-structured household survey questionnaires were used. A sample of 218 households was selected randomly to include both tree farmers and non-tree farmers in Kiryanga Sub County. The descriptive summaries and content analysis were used in data analysis. Results indicate that Eucalyptus spp., Pinus spp., and fruit trees were most preferred. Farmers have different tree species' preferences due to the benefits obtained from them. Provision of these suitable tree species' seedlings will highly incentivize and enhance tree planting in Uganda.
\end{abstract}

Keywords: tree-species preferences, Albertine rift, tree planting

\section{Introduction}

There have been several efforts to increase tree cover in Uganda by different actors. Ugandan government intends to increase forest cover from the current 9\% to 24\% by 2040 (National Planning Authority 2013). Uganda also pledged to restore 2.5 million hectares of deforested land by 2020 in the Bonn Challenge (Ministry of Water and Environment 2016a). This is because trees support livelihoods of people by providing ecosystem services such as regulating climate, preserving soil fertility and sequestering carbon (Salmond et al. 2016). Tree cover in Uganda is still reducing (World Vision Uganda 2014; IUCN 2018; National Environmental Management Authority 2016) because farmers and other actors have not adequately embraced tree planting (Ministry of Water and Environment 2016). This is probably due to compelling farmers to plant trees against their wish.

One of the innovations to promote tree planting is distributing tree seedlings to potential farmers. The use of tree seedling incentives can be essential in order to stimulate small-scale tree planting but the right tree species have to be promoted (Nabanoga et al. 2012). The tree species most

\footnotetext{
* Corresponding author: Charles Lwanga Tumuhe e-mail: tumchaz34@gmail.com
} 
important in agroforestry systems in Uganda, are dependent on location and benefits obtained from them (Kalanzi and Nansereko 2014). Some of tree species most preferred in agro-forestry systems in Uganda include; Ficus nantalensis, Artocarpus heterophyllus, Maesopsis eminii, Mangifera indica, and Persea americana (Kalanzi and Nansereko 2014). In the Albertine rift there is a range of tree species that are grown on farmlands for different purposes. These include, among others, Ficus spp., Euphorbia spp., and Cascabela thevetia (Kakuru et al. 2014). Farmers will choose to plant or conserve tree species because of the goods and services these trees provide (Alao and Shuaibu 2011). These goods and services are generally called ecosystem services. (Salmond et al. 2016). However, soil properties say nutrient content and $\mathrm{pH}$ and other biophysical factors like temperature also determine tree species that will grow in an area (Londo et al. 2006). Therefore tree species established in a given location are those that are beneficial to farmers and are supported by the existing agro-ecological conditions. This study assesses tree species preferences by farmers in Kiryanga Sub County (SC), Albertine rift region, Uganda.

\section{Methodology}

\section{Description of study area}

Kiryanga SC (Fig. 1) is located between $1^{\circ} 5^{\prime} 40^{\prime \prime}$ North, and $31^{\circ} 3^{\prime} 32^{\prime \prime}$ East. Modified Equatorial vegetation type mainly covers Kiryanga SC (Langdale et al. 1964). This type of vegetation used to be equatorial in nature but has been modified as a result of human activity. Rainfall ranges from $1000 \mathrm{~mm}$ to $1500 \mathrm{~mm}$, soils are Ferrallistic and temperature ranges from $15 \mathrm{oC}$ to $30 \mathrm{oC}$ (Kakuru, Doreen, and Wilson 2014). Crops grown in Kiryanga SC include maize, cassava, potatoes, bananas, tobacco, rice and beans (Uganda Bureau of Statistics 2016). Trees commonly cultivated include; Melia azedarach L., Markhamia lutea (Benth.) K. Schum., Vitellaria paradoxa C.F. Gaertn., Senna spectabilis (DC.) H.S. Irwin \& Barneby, Tamarindus indica L., Eucalyptus spp., Ficus spp., Euphorbia spp., Cascabela thevetia (L.) Lippold and Combretum spp. These trees are important because they provide food, medicine, fuelwood, building poles, shade, windbreaks, and source of income through the sale of fuelwood (Kakuru, Doreen, and Wilson 2014). Kiryanga SC borders with four forest reserves; Rwengeye, Ruzaire Kasato, and Kyamurangi in Kagadi sector (Nyakana and Nyakana n.d.). Due to its location, Kiryanga's rate of forest cover loss is 10 percent per year and about five times higher than the (1.8 percent) national forest cover loss rate (Ministry of Water and Environment 2016). Kiryanga SC was thus selected for this study because it is one of the eight Sub Counties in Albertine rift, the Murchison-Semliki REDD+ Project has been involved in incentive-based tree planting mainly using free tree seedlings as incentives (Wieland 2012). Furthermore, Kiryanga is located in the Albertine Rift whose forests are under threat due to various factors leading to loss of biodiversity. There is an increasing threat from rural communities whose high levels of poverty make them dependent on forest resources. Conservation International listed the Albertine Rift as one of the world's most endangered areas, based on levels of species' endemism and rates of habitat destruction (National Environmental Management Authority 2009).

\section{Research Design}

This study adopted a cross - sectional descriptive survey research design which involved collection of data from a random sample at one point of time. The survey was carried out in March 2018 to assess tree species preferences of farmers in Kiryanga SC. 


\section{Research Approach}

The study involved both quantitative and qualitative methods. Data collection took a mixed methods approach (Ward et al. 2018) comprising of Key Informant Interviews (KII), Focus Group Discussions (FGD) (for qualitative data) and household questionnaires (for quantitative data).

\section{Data Collection techniques and instruments}

\section{Key Informant Interviews}

Eleven KIIs were conducted. The KII participants within the study area were selected purposively with the guidance of the Sub County Chairperson and Agricultural Officer depending on the positions and experiences they had in tree planting. The key informants selected were from Sub County, District, National Forestry Authority and tree farmer associations. The key informants were asked about the existing and desirable tree species in the study area. The responses were audio recorded and later typed in Microsoft word.

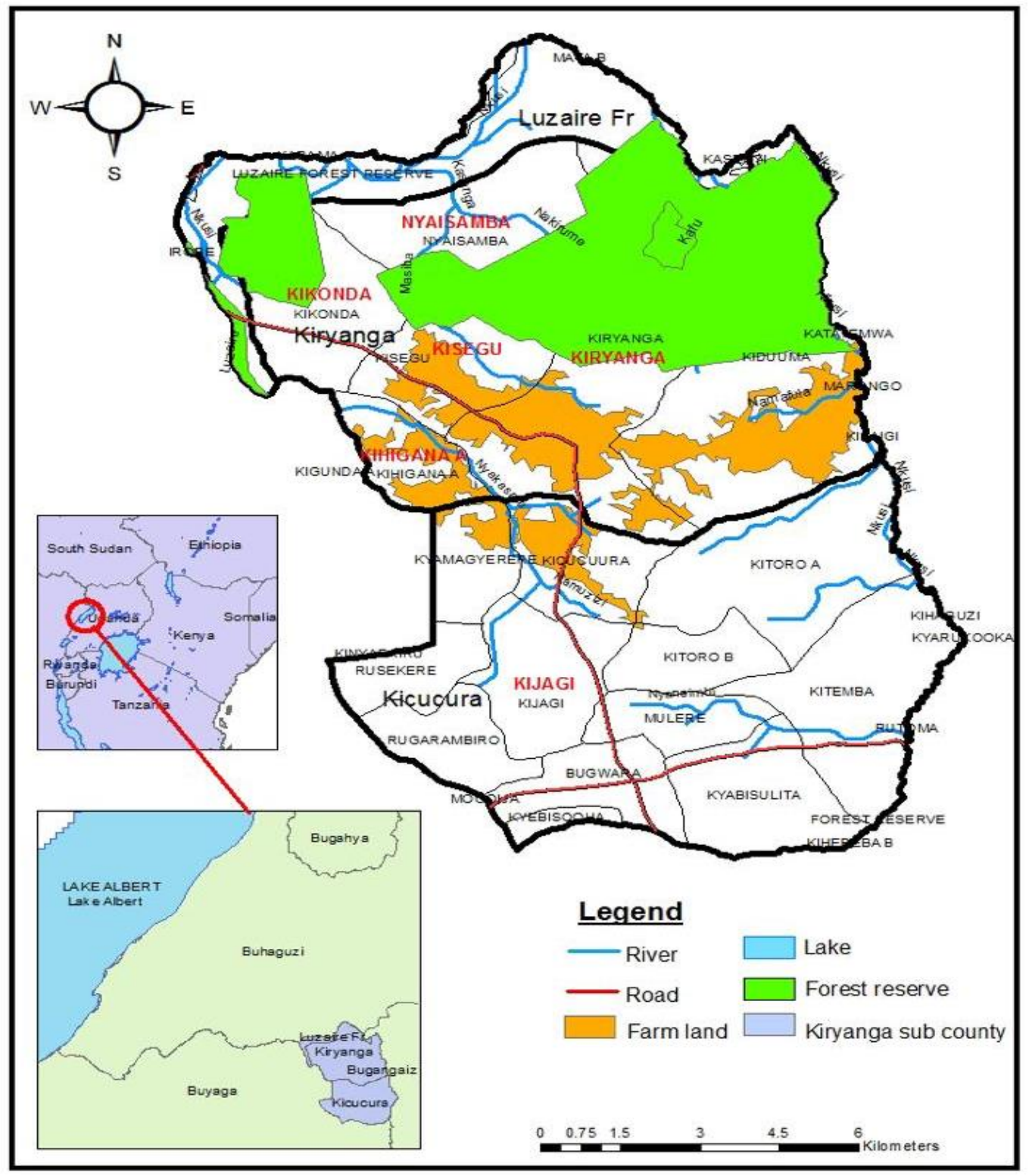

Fig. 1. Location of the study area. The smaller 2 maps on the left show location of the Albertine rift region and the bigger and centered map show Kiryanga SC (study area). 


\section{Focus Group Discussions}

FGDs were organized at Sub County and Parish levels. FGD participants were selected purposively by Sub County Agricultural Officer to have a representation of both tree and non-tree farmers. Each FGD had 6-12 people totaling sixty people. The participants were categorized into tree farmers and non-tree farmers to ensure homogeneity. These were interviewed using predetermined questions. There were mixed FGDs (male and female), only male and only female FGDs as well. The FGD participants were asked what tree species were more desirable to them. FGD participants were asked to rank these species collectively. For this ranking, we distributed 100 seeds to each group (Fig. 2). Respondents were asked to distribute them among the responses mentioned according to how they viewed their importance (Fig. 2). The most important species got the highest number of seeds and the least important, the least number of seeds.

\section{Household surveys}

The researcher administered survey questionnaires to the 218 households. The Researcher moved together with a field guide. This was done to introduce him to the respondents and to assure the respondents of local peoples' approval, but also to build rapport between researcher and respondents (Fig. 3). The purpose of the study was explained to respondents, and the anonymity of responses, confidentiality and data protection were all emphasized. The languages used in the survey were Runyoro, Rutooro, Runyankole, and Rukiga. The questionnaire had questions on tree species mostly preferred by farmers. All tools used were first translated from English to Runyoro and back-translated to English to ensure clarity of questions.

\section{Sampling procedure}

The multistage sampling procedure was used whereby Kiryanga SC was purposively selected from the eight Sub Counties Bugambe, Kabwoya, Kitoba, Kyabigambire, Kakindo, Kiziranfumbi, Birembo and Kiryanga where the Murchison-Semliki REDD+ Project has been involved in incentivebased tree planting (Wieland 2012). One village per parish was randomly selected making a total of four villages. In each village, the households were put in two categories; tree farmers and non-tree farmers and samples were randomly drawn from non-tree farmers but all tree farmers were considered due to their small number. Tree farmers, for purposes of this study, were those with more than 50 trees on their farm by the time of the study. The formula for determining sample size for research activities (Krejcie and Morgan 1970) was used to get the appropriate total sample size. The required sample size for each village was established basing on the total number of households in each village (Tab. 1). A total of 237 households were required but 218 households were however included and 19 households (non-tree farmers) in Kijagi village could not be accessed.

Tab. 1. Respondents (tree planters and non-tree planters) interviewed in the household questionnaire survey. The table shows total number of households per village, required and actual number of households sampled for both tree- and non-tree farmers in each village in Kiryanga SC.

\begin{tabular}{cccccccc}
\hline Parish & Village & $\begin{array}{c}\text { Number of } \\
\text { Households }\end{array}$ & Percent & $\begin{array}{c}\text { Required } \\
\text { Sample Size }\end{array}$ & $\begin{array}{c}\text { Households } \\
\text { Sampled }\end{array}$ & $\begin{array}{c}\text { Tree } \\
\text { farmers }\end{array}$ & $\begin{array}{c}\text { Non-tree } \\
\text { farmers }\end{array}$ \\
\hline Kikonda & Kiseegu & 134 & 21.6 & 51 & 51 & 11 & 40 \\
Kitooro & Kitooro C & 162 & 26.1 & 62 & 62 & 47 & 15 \\
Kiryanga & Kiryanga B & 191 & 30.8 & 73 & 73 & 30 & 43 \\
Kicucuura & Kijagi & 133 & 21.5 & 51 & 32 & 15 & 17 \\
Total & & $\mathbf{6 2 0}$ & $\mathbf{1 0 0}$ & $\mathbf{2 3 7}$ & $\mathbf{2 1 8}$ & $\mathbf{1 0 3}$ & $\mathbf{1 1 5}$ \\
\hline
\end{tabular}


The researcher moved with a field guide to administer the survey questionnaires. The field guide introduced the researcher and built rapport between the Researcher and respondents. The questions covered demographic characteristics, existing and preferred tree species and their uses. The purpose of the study was explained to the respondents, and anonymity of responses, confidentiality and data protection were all emphasized. The languages used in the survey were Runyoro, Rutooro, Runyankole and Rukiga.

\section{Data analysis}

Data from KII, and FGDs were transcribed and translated from vernacular to English. It was analyzed inductively and manually using content analysis. It was condensed into meaning units and then coded. Themes were identified and organized into meaningful categories. Other responses were presented as verbatim quotes. The median scores for tree species preferred were computed using the Microsoft Excel program.

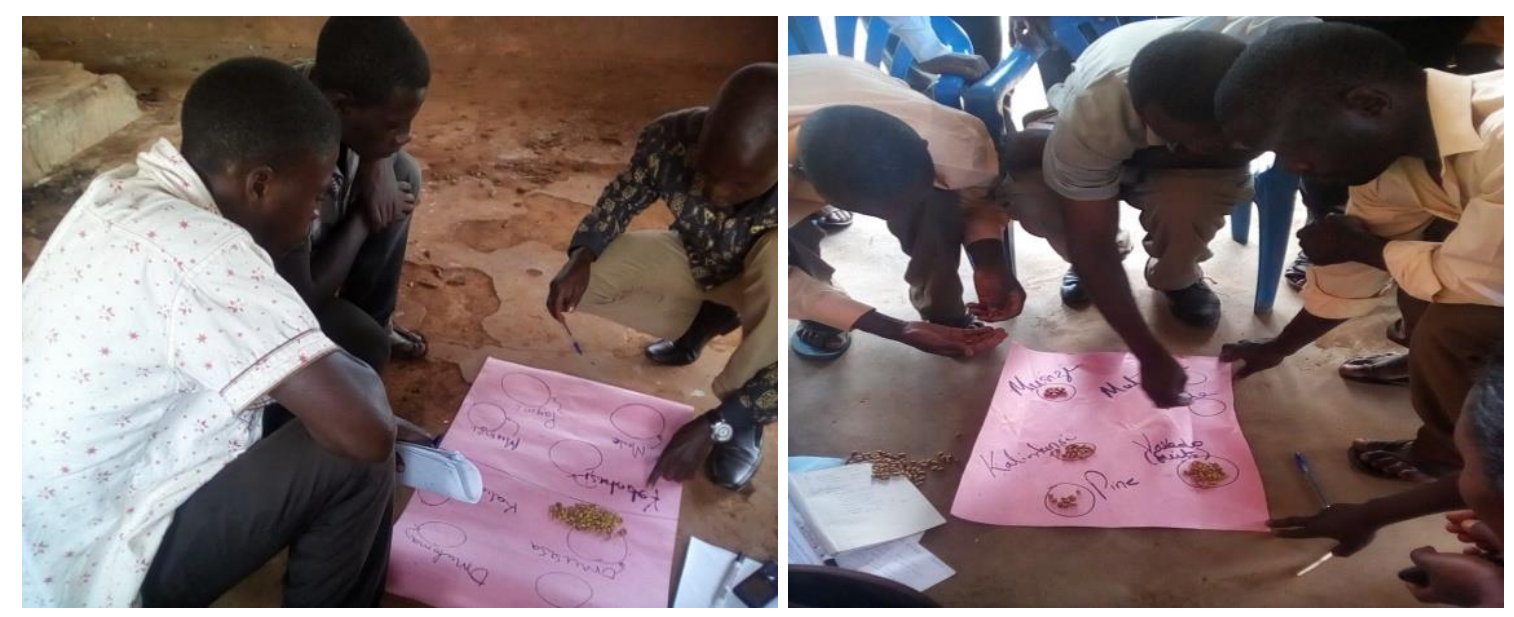

Fig. 2. The scoring exercise of the preferred tree species by the male CFM, FGD participants.

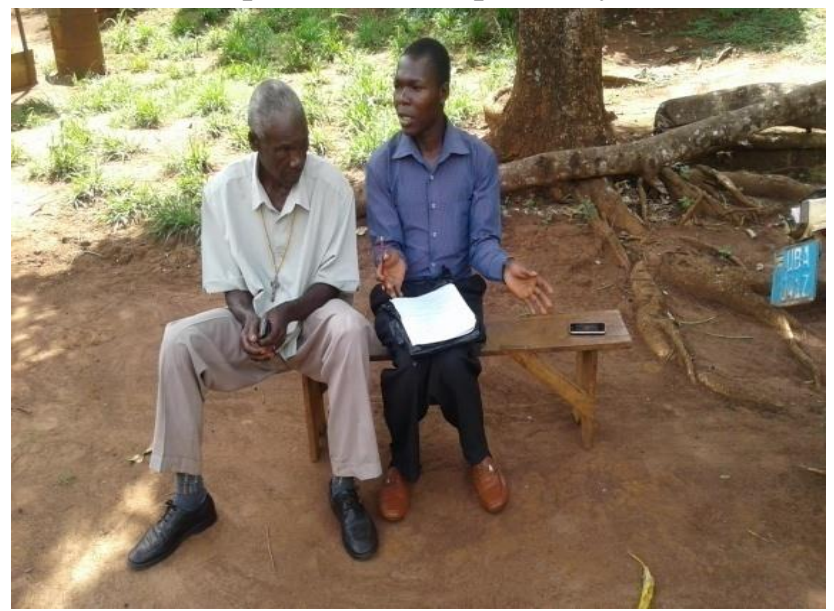

Fig. 3. One of the respondents being interviewed at his home in Kiryanga B village during the household survey.

\section{Results}

There are 13 important tree species that are existing in the study including; Eucalyptus spp., Markhamia lutea. Artocarpus heterophyllus, Mangifera indica L., Persea americana Mill., Coffea spp., Maesopsis eminii Engl., Pinus spp., Senna spectabilis, Khaya anthotheca (Welw.) C.DC, Milicia excelsa, Albizia coriaria, and Ficus nantalensis. From the above list, three tree species were more preferred including; Eucalyptus spp., Pinus spp., and Mangifera indica L. Eucalyptus spp. was 
mentioned by all focus groups and given the highest score. Household survey results indicate that this Eucalyptus tree was even the most dominant tree species in the study area. Pinus spp. was also mentioned by all focus groups as a preferred tree species. The average scores assigned to these trees are indicated in below (Tab. 2).

These tree species were preferred for various reasons. The main reason for planting Eucalyptus spp. was for its relatively higher rate of growth and thus bringing quick income to farmers from the sale of its timber products. Additionally, its seedlings were the most available and easily accessible by farmers. Respondents said that this tree is planted for cutting timber and getting firewood to spare other tree species. Pinus spp. is preferred because it is a good repellant against crop pests. Its leaves and wood chippings burn so fast and thus are used to light fire. It is also preferred because it does not spoil soil, grows with other crops and can later be cut into timber (Tab. 2). Mangifera indica is preferred because it can both be eaten and sold for income. It is mainly planted but it also establishes itself from dumped seeds. It is liked for providing medicinal herbs to farmers. It is also preferred because its seedlings are easier to access.

Tab. 2 The most mentioned and preferred tree species in the household survey. The mentioned tree species are the existing most important species to the people in the study area. Farmers' preferences of tree species basing on scores were assigned by focus groups. Three tree species mentioned by all focus groups and their assigned scores are shown. The possible minimum and maximum scores are 0 and 100.

\begin{tabular}{|c|c|c|c|}
\hline $\begin{array}{l}\text { Name of tree } \\
\text { species }\end{array}$ & Freq. & $\begin{array}{l}\text { FGD } \\
\text { score }\end{array}$ & The reason it was planted/preserved \\
\hline Eucalyptus spp. & 18 & 33 & $\begin{array}{l}\text { Seedlings are more available, it rarely establishes itself, } \\
\text { planted for cutting timber, grows quickly and thus gives } \\
\text { quicker income. Its leaves cure stomach pain and malaria. } \\
\text { It provides more suitable wood for curing tea }\end{array}$ \\
\hline Pinus spp. & 2 & 18 & $\begin{array}{l}\text { It grows quickly and provides hard timber that is highly } \\
\text { marketable }\end{array}$ \\
\hline $\begin{array}{l}\text { Mangifera } \\
\text { indica L. }\end{array}$ & 8 & 15 & It gives income and has edible fruits \\
\hline Coffea spp. & 8 & 6 & $\begin{array}{l}\text { Gives high income from the sale of berries, dropping leaves } \\
\text { improve soil fertility }\end{array}$ \\
\hline $\begin{array}{l}\text { Artocarpus } \\
\text { heterophyllus } \\
\text { Lam. }\end{array}$ & 12 & 3 & $\begin{array}{l}\text { It's for eating and providing shade, fruits sold for income, It's a } \\
\text { more suitable lightning arrester }\end{array}$ \\
\hline $\begin{array}{l}\text { Persea } \\
\text { americana Mill. }\end{array}$ & 8 & 3 & It is used as a "cosmetic", has edible fruits and gives income, \\
\hline $\begin{array}{l}\text { Markhamia } \\
\text { lutea } \text { (Benth.) } \\
\text { K. Schum. }\end{array}$ & 14 & 1 & $\begin{array}{l}\text { It adds on soil fertility, makes good charcoal and firewood, and } \\
\text { doesn't spoil soil; its wood is good for construction, suitable for } \\
\text { making tool handles. It's both medicinal and ornamental. Grows } \\
\text { relatively quicker, and it's a favorable windbreaker } \\
\text { Other trees species (see appendix } 1 \& 2\end{array}$ \\
\hline
\end{tabular}

\section{Discussion}

Tree species are mainly selected depending on services they provide to farmers in the study area. These mainly include providing food, medicinal herbs, and shade and wood products. The tree species most preferred in Kiryanga were Eucalyptus spp., Mangifera indica L. and Pinus spp. However tree species selected by farmers in Masaka district are different and these included; Ficus nantalensis, Artocarpus heterophyllus, Maesopsis emnii, Mangifera indica and Persea americana. The trees were 
selected because they offer optimal shading in Coffee gardens (Kalanzi and Nansereko 2014). The Saw Log Production Grant Scheme project promotes Eucalyptus grandis and Pinus caribaea trees because they are the commercially grown trees in most plantations in Uganda (Kaboggoza 2011). Biophysical factors like soil properties are likely to affect farmers' tree-species' preferences. For example, Acacia koa tree restoration in Hawaii did not allow regeneration of native tree species due to increased Nitrogen content by the Acacia koa trees (Yelenik 2017). The choice of tree species, location, and density are therefore guided by biophysical factors and impacts of these trees on the environment (Salmond et al. 2016). Tree species do not exist in the different parts of the world by mere coincidence. Their existence could a result of some of the above factors. This is possibly why successful tree planting programs start with identifying tree species to promote before the projects are implemented.

\section{Conclusions}

Farmers have varying preferences for different tree species because of the goods and services these trees provide. Among the existing trees in the study area, the suitable tree species for consideration in incentivized tree planting projects are Eucalyptus spp., followed by Mangifera indica and Pinus spp. They are the most preferred trees by farmers and they also grow best in their locality.

\section{Acknowledgement}

I appreciate Professor J.R.S Tabuti and Dr. Juliet Kiguli who supervised this work. I thank NORAD, through the NORHED project (UGA-13/0019), which supported this work financially. The Uganda National Council for Science and Technology (NS - 511) provided permission to conduct this study. The SC chief and chairperson local council III, Kiryanga SC, permitted the data collection in their area.

\section{References}

IUCN (2018) Assessing IUCN Contribution to Uganda's Forest Landscape Restoration Processes. Kampala, Uganda.

Kaboggoza J (2011) Forest Plantations and Woodlots in Uganda. Vol. 1. Nairobi. www.afforum.org\%0A1\%0ADisclaimer.

Kakuru OV, Doreen M, Wilson M (2014) Adoption of On-Farm Tree Planting in Kibaale District, Western Uganda. Journal of Sustainable Forestry 33 (1): 87-98. https://doi.org/10.1080/10549811.2013.776965.

Kalanzi F, Nansereko S (2014) Exploration of Farmers' Tree Species Selection for Coffee Agroforestry in Bukomansimbi District of Uganda. International Journal of Research on Land-Use Sustainability 1: $9-16$.

Langdale BL, Osmaston HA, Wilson JG (1964) The Vegetation of Uganda and Its Bearing on Land Use. Kampala.

Londo AJ, Kushla JD, Carter RC (2006) Soil PH and Tree Species Suitability in the South. Southern Regional Extension Forestry.

Ministry of Water and Environment (2016) State of of Uganda's Forestry 2016. Kampala. www.mwe.go.ug.

Nabanoga G, Namaalwa J, Ssenyonjo (2012)The Ongo Community Forest REDD + Pilot Project , Uganda A Socioeconomic Baseline Survey." London.

National Environmental Management Authority (2009) Fourth National Report To The Convention On Biological Diversity. Kampala, Uganda.

National Planning Authority (2013) Uganda Vision 2040. Kampala, Uganda. http://npa.ug/ugandavision-2040/.

Nyakana F, Nyakana G (nd) Kibaale District Hydrochemical Characteristics Map.

Salmond JA, Tadaki M, Vardoulakis S, Arbuthnott K, Coutts A, Demuzere M, Dirks KN, et al. (2016) Health and Climate Related Ecosystem Services Provided by Street Trees in the Urban Environment. Environmental Health 15 (36): 95-111. https://doi.org/10.1017/S1755267214001316. 
Charles Lwanga Tumuhe and Sylvia Nyamaizi

Uganda Bureau of Statistics (2016) National Population and Housing Census 2014 - Main Report. Uganda Bureau of Statistics. Kampala, Uganda. https://doi.org/10.1017/CBO9781107415324.004.

Ward C, Stringer LC, Holmes G (2018) Protected Area Co-Management and Perceived Livelihood Impacts. Journal of Environmental Management 228: 1-12. https://doi.org/10.1016/j.jenvman.2018.09.018.

Wieland M (2012) Murchison - Semliki REDD + Project Free , Prior and Informed Consent Approach." Kampala, Uganda.

World Vision Uganda (2014) 2014 Annual Report. Kampala, Uganda.

Yelenik SG (2017) Linking Dominant Hawaiian Tree Species to Understory Development in Recovering Pastures via Impacts on Soils and Litter. Restoration Ecology 25 (1): 42-52. https://doi.org/10.1111/rec.12377. 